ISSN 0258-7122

Bangladesh J. Agril. Res. 36(3) : 381-387, September 2011

\title{
EFFECT OF PRESERVED SEEDS USING DIFFERENT BOTANICALS ON SEED QUALITY OF LENTIL
}

\author{
A. KhATUN ${ }^{1}$, G. KABIR ${ }^{2}$, M. A. H. BhUIYAN ${ }^{3}$ AND D. KhANAM ${ }^{4}$
}

\begin{abstract}
Laboratory studies were conducted with leaf powder of three plants to show the preservative effect for maintaining the quality of lentil seeds in storage. After processing and drying, seeds were preserved with different botanicals and stored them in earthen pots for eight months. Botanicals, such as whole leaf powder of neem (Azadirachta indica), dholkalmi (Ipmoea sepiara), and bishkatali (Polygonum hydropiper) were used at a dose of 5\% w/w (25 g botanical per 500 $\mathrm{g}$ of lentil seeds). The lentil seeds were stored till next planting time and seed quality, such as moisture content, germination capacity, root length, shoot length of the seedlings and vigour index were observed. The highest values for all these characters except moisture content were significant when the seeds were preserved with neem leaf powder and bishkatali. Among three botanicals, dholkalmi was less effective.
\end{abstract}

Keywords: Lentil, botanicals, storage. seed quality.

\section{Introduction}

Pulses play an important role as the supplement of protein in the diet of the people of Bangladesh. Lentil is the important pulse crop grown in Bangladesh in order to meet the domestic needs. It is the second most important pulse crop in respect of area and production, but it stands first in the consumer's preference in this country (Afzal et al., 2003) and contributes about $40 \%$ to the total pulses production (Anon., 2006). Seed quality is the prerequisite condition that affects the germination and yield of any crop plants. This condition is directly related with the factors like moisture content, seed drying temperature and relative humidity around seed storage, types of storage container and storage period. Recently, the use of different plant parts and their derivatives has appeared to be an effective alternative to poisonous chemical insecticides for controlling various insect pests in storage. In the world, as many as 2400 plant species have been recorded that have potential pesticidal properties and biological activity against a wide range of pests (Grainge and Ahmed, 1988). Being situated in the tropical region, Bangladesh has a rich botanical biodiversity, which contains innumerable plant species having medicinal and pesticidal properties (Karim, 1994).

${ }^{1}$ Principal Scientific Officer, Irrigation and Water Management Division, Bangladesh Agricultural Research Institute (BARI), Joydebpur, Gazipur-1701, ${ }^{2}$ Professor, Department of Botany, Rajshahi University, Rajshahi 6205, ${ }^{3}$ Senior Scientific Officer, Soil Science Division, BARI, Joydebpur, Gazipur-1701, ${ }^{4}$ Senior Scientific Officer, Biotechnology Division, BARI, Joydebpur, Gazipur-1701, Bangladesh. 
In storage, lentil seeds deteriorate its quality due to fungal, insect or other pest infestation. Different botanicals can be used for protection of seeds. Uses of different chemicals are costly and may cause natural hazard, whereas botanicals are less costly, easily available to the farmers and safe to handle. Comparative study of botanicals helps to choose the suitable one for storing the seeds of lentil. The studies were carried out to determine the effects of three botanicals viz., leaf powder of neem (Azadirachia indica), dholkalmi (Ipmoea sepiara), and bishkatali (Polygonum hydropiper) on the seed quality of lentil.

\section{Materials and Method}

Studies were carried out in the laboratory of Seed Technology Division, Bangladesh Agricultural Research Institute (BARI), Jovdebpur, Gazipur. Lentil (BARI Masur-2) seeds used in the study were collected from Pulses Research Centre's experimental field, BARI, Gazipur during the rabi seasons of 2003-04 kept in earthen pots and stored in normal condition.

The test botanicals were leaf powder of neern (Azadirachta indica), dholkalmi (Ipmoea sepiara) and bishkatali (Polygonum hydropiper). The leaves of these plants were collected from different villages of Gazipur. The collected leaves were dried under ambient room temperature $\left(27^{\circ} \mathrm{C}\right.$ to $\left.34^{\circ} \mathrm{C}\right)$, grinded separately by a hand grinder and passed through a 60 - mesh sieve to get fine powder. Clean and fresh lentil (BARI Masur-2) seeds were taken from the seed lot and sun dried to maintain 9-10\% moisture content.

The seeds were then divided into four parts. One part was considered as control $\left(\mathrm{T}_{4}\right)$ i.e. without any botanical treatment. Other three parts were treated with three different botanicals at the dose of $5 \%$ w/w i.e., $25 \mathrm{~g} / 500 \mathrm{~g}$ of lentil seeds (Bhuiyah, 2001) with six replications. Before storage, seeds were analyzed for germination, moisture content, and vigour index. The seeds were stored in March till next planting time and seed quality was observed during August to September in 2004 and 2005. Data on moisture content, germination capacity, root length, shoot length, root plus shoot length and vigour were recorded. Average germination percentage of the seed lot before storage was $90 \%$ and average moisture content of the seed before storage was $9 \%$.

The moisture content of seed samples were determined following the rule of ISTA, 1976. Germination test was carried out according to ISTA rule of 1976. For each treatment, 100 seeds were placed in Petri dishes (8.50 cm diameter). Six replicates were used. The Petri dishes were kept on a laboratory table at room temperature $\left(25 \pm 2^{\circ} \mathrm{C}\right)$. After ten days, normal, abnormal, and diseased seeds were counted.

After eight days, ten plants were randomly selected from each replicate of each treatment. The seedlings were cut into root and shoot parts. They were 
measured (in cm) and the mean value was computed. Seed vigour was calculated as percent germination $x$ length of seedling (Reddy and Khan, 2001).

The data for different parameters were compiled and subjected to statistical analysis following a computer IRRISTAT and MSTAT package programme (Freed, 1992) adjusting the means. The correlation co-efficient and regression analysis were done for different variables wherever needed using Microsoft Excel Programme 1997.

\section{Results and Discussion}

\section{Moisture content of lentil seeds}

No significant difference in percent moisture among different botanicals was observed in both 2004 and 2005 (Table I). The percent of moisture content of lentil seeds increased by $1 \%$ in untreated (control) condition compared to lower moisture in treated seeds particularly with neem leaf powder. It indicated that botanicals had no effect on seed moisture content. Shahjahan (2003) observed that lentil seeds contained 8.57-11.45\% moisture content after nine months of storage kept in six types of containers. Khatun et al. (2008) found that moisture content of lentil seeds ranged from 8.19 to $10.36 \%$.

\section{Germination of lentil seeds}

There was a significant effect on germination using different botanicals (Table I). The germination was the highest in the seeds stored with neem leaf powder and recorded $86.0 \%$ and $87.2 \%$ in two years, and statistically identical to bishkatali treatment. Dholkalmi and untreated seeds showed less and similar germination. The factor, such as lower moisture content of lentil seeds stored with bishkatali and neem might cause the greater germination. Savitri el al. (1994) found that neem leaf powder gave higher germination $(65.7 \%)$ of sorghum seeds, while control treatment i.e., without any botanicals gave lower germination rate (61.3\%). Bhuiyah (2001) observed that there was no significant difference in the germination of lentil seeds among the treatments, such as leaf powder of neem, bankalmi and biskhatali had no adverse effect on the germination of lentil, while their viability was retained for a storage period of four months. Khatun et al. (2008) reported 84.3 to $94.2 \%$ germination in lentil when seeds were stored.

\section{Root length}

There was no significant effect of botanicals on root length of lentil. The root length ranges from 8.49 to $8.75 \mathrm{~cm}$ in two years (Table I). This might be due to higher germination rate which might cause higher root length. Khatun et al. (2009) found that root length of lentil seedlings was 7.20-11.10 cm. 
Table 1. Different parameters of lentil seeds preserved with three botanicals under laboratory condition in two years.

\begin{tabular}{l|l|l|l|l|l|l}
\hline Botanicals & $\begin{array}{c}\text { Moisture } \\
\text { content }\end{array}$ & $\begin{array}{c}\text { Germination } \\
\text { capacity }\end{array}$ & $\begin{array}{c}\text { Root } \\
\text { length } \\
(\mathrm{cm})\end{array}$ & $\begin{array}{c}\text { Shoot } \\
\text { length } \\
(\mathrm{cm})\end{array}$ & $\begin{array}{c}\text { Root }+ \\
\text { shoot } \\
\text { length } \\
(\mathrm{cm})\end{array}$ & Vigour \\
\hline 2004-05 & & & & & \\
\hline Neem & 8.44 & $86.0 \mathrm{a}$ & 8.75 & $7.83 \mathrm{a}$ & $16.58 \mathrm{a}$ & $1428 \mathrm{a}$ \\
Bishkatali & 8.91 & $85.5 \mathrm{a}$ & 8.70 & $7.60 \mathrm{ab}$ & $16.31 \mathrm{a}$ & $1395 \mathrm{ab}$ \\
Dholkalmi & 8.98 & $74.2 \mathrm{~b}$ & 8.57 & $7.43 \mathrm{~b}$ & $16.00 \mathrm{ab}$ & $1186 \mathrm{bc}$ \\
Control & 9.46 & $72.8 \mathrm{~b}$ & 8.52 & $6.97 \mathrm{c}$ & $15.32 \mathrm{~b}$ & $1123 \mathrm{c}$ \\
\hline LSD (0.05) & - & 10.14 & - & 0.52 & 0.88 & 210 \\
\hline 2005-06 & & & & & & $1529 \mathrm{a}$ \\
\hline Neem & 8.87 & $87.2 \mathrm{a}$ & 8.60 & $8.91 \mathrm{a}$ & 17.51 & $1498 \mathrm{a}$ \\
Bishkatali & 8.93 & $86.7 \mathrm{a}$ & 8.55 & $8.80 \mathrm{a}$ & 17.30 & $1220 \mathrm{~b}$ \\
Dholkalmi & 9.11 & $73.4 \mathrm{~b}$ & 8.51 & $8.12 \mathrm{ab}$ & 16.64 & $1 \mathrm{l} 32 \mathrm{~b}$ \\
Control & 9.40 & $71.6 \mathrm{~b}$ & 8.49 & $7.32 \mathrm{~b}$ & 15.81 & 260.72 \\
\hline LSD (0.05) & - & 11.85 & - & 1.09 & - &
\end{tabular}

In a column, having common letter did not differ significantly at $5 \%$ level

\section{Shoot length}

The shoot length of lentil seeds after germination differed significantly due to application of botanicals in both the years (Table 1). The highest shoot length of $7.83 \mathrm{~cm}$ in 2004 and $8.91 \mathrm{~cm}$ in 2005 was recorded in seedlings raised from seeds treated with neem leaf powder and it was identical to that of bishkatali. The lowest shoot length of $6.97 \mathrm{~cm}$ in 2004 and $7.32 \mathrm{~cm}$ in 2005 was found in control condition. Khatun et al. (2009) found 7.40-9.45 cm shoot length in lentil.

\section{Root plus shoot length}

The highest root and shoot length together measured $16.58 \mathrm{~cm}$ in 2004 when the seeds were stored in neem leaf powder and this was identical to other treatments (Table 1). The root and shoot length was not significantly different in 2005. The untreated seeds produced seedlings with less root and shoot length. Khatun et al. (2009) found $16.53-29.80 \mathrm{~cm}$ in lentil seedlings.

\section{Vigour index}

The vigour index increased in the second year. Lentil seeds preserved with neem leaf powder showed the highest vigour index of 1428 and 1529, which was statistically identical to bishkatali preserved seeds in both the years. This might 
be due to higher rate of germination and higher root and shoot length. Both Dholkalmi treated seeds and untreated seeds had statistically identical vigour index and the lowest among the treatments. It indicated that Dholkalmi couldn't show an appreciable result on vigour. Savitri et al. (1994) found higher vigour (1278) in sorghum seeds stored with neem leaf powder compared to vigour (1079) in untreated seeds (control). Khatun et al. (2008) observed vigour index values in a range of 1439 to 2780 in lentil seeds. In another study, Khatun et al. (2009) also found 1343 to 2005 vigour in lentil seeds.

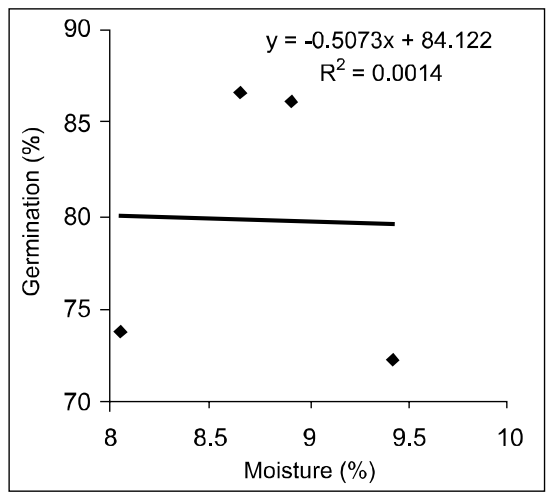

Fig. 1. Relationship between moisture content and germination (\%) of lentil (based on average values of two year's data).

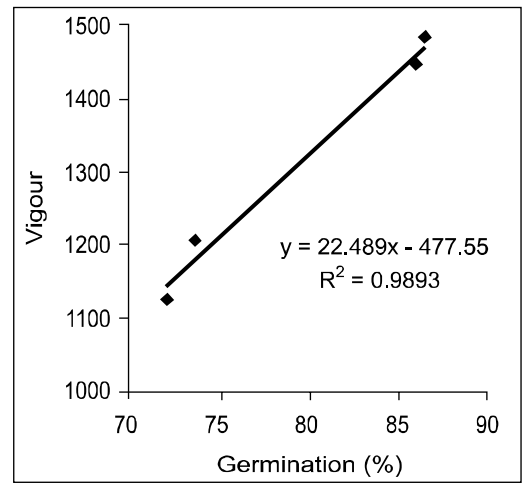

Fig. 3. Relationship germination (\%) and vigour of lentil (based on average values of two years' data).

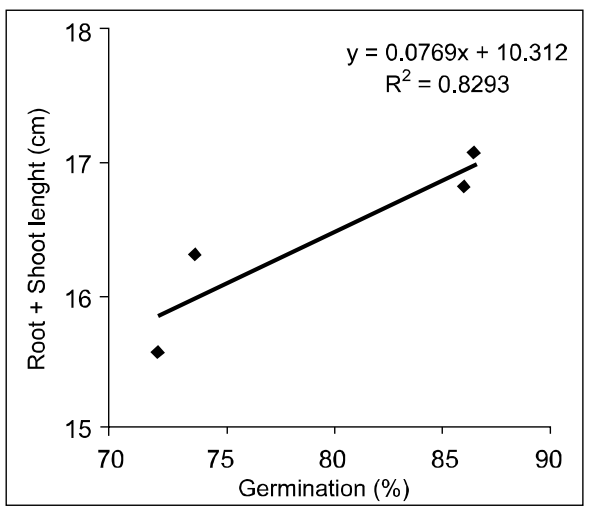

Fig. 2. Relationship between germination (\%) and root plus shoot lenght of lentil (based on average values of two year's data).

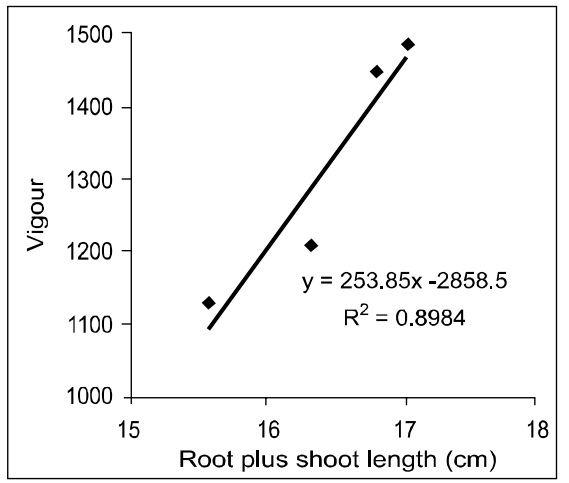

Fig. 2. Relationship between root plus shoot length and vigour of lentil (based on average values of two years' data).

Correlation matrix among the plant characters of lentil has been shown in Table 2. A positive and significant correlation was observed between germination capacity and roots plus shoot length in 2004, and germination 
capacity and vigour in 2004 and 2005. Positive and significant correlation was also observed between root plus shoot length and vigour both in 2004 and 2005. Reddy and Khan (2001) found positive and significant correlation of germination with seedling dry weight and vigour index. Results reported by Baburatan et. al. (1993) and Ponnuswamy et al. (1991) were found to be close agreement with the present findings. Positive and linear correlations was observed between germination capacity and root plus shoots length (Fig. 2), germination capacity and vigour (Fig. 3), root plus shoot length and vigour (Fig. 4). But negative and linear correlation was observed between moisture content and germination capacity (Fig. 1). Khatun et al. (2008 and 2009) also found positive and significant correlation of germination percentage with root plus shoot length and vigour, and root plus shoot length with vigour.

Table 2. Correlation matrix among different parameters of lentil.

\begin{tabular}{|c|c|c|c|c|c|c|}
\hline \multirow{3}{*}{ Characters } & \multicolumn{6}{|c|}{ Correlation coefficient (r value) } \\
\hline & \multicolumn{2}{|c|}{ Germination capacity } & \multicolumn{2}{|c|}{ Root + shoot length } & \multicolumn{2}{|c|}{ Vigour } \\
\hline & 2004 & 2005 & 2004 & 2005 & 2004 & 2005 \\
\hline Moisture content & $-0.227^{\mathrm{ns}}$ & $-0.057^{\mathrm{ns}}$ & $-0.061^{\mathrm{ns}}$ & $0.279^{\mathrm{ns}}$ & $-0.189^{\mathrm{ns}}$ & $0.10^{\mathrm{ns}}$ \\
\hline $\begin{array}{l}\text { Germination } \\
\text { capacity }\end{array}$ & - & - & $0.609 *$ & $0.330^{\mathrm{ns}}$ & $0.958 * *$ & $0.870^{* *}$ \\
\hline $\begin{array}{l}\text { Root }+ \text { shoot } \\
\text { length }\end{array}$ & - & - & - & - & $0.808 * *$ & $0.751 * *$ \\
\hline
\end{tabular}

* Significant at 5\% level, ** Significant at $1 \%$ level, NS: Not significant

\section{References}

Afzal, M. A., M. A. Bakr, A. Hamid, M. M. Haque and M. S. Aktar. 2003. Lentil in Bangladesh. Lentil, Blackgram and Mungbean Development Pilot Project, Pulses Research Station, BARI, Gazipur- 1701. Publication No. 24: 27-31.

Anonymous. 2006. Statistical Yearbook of Bangladesh. 26th Edition. Bangladesh Bureau of Statistics, Planning Division, Ministry of Planning, Govt. of the People's Republic of Bangladesh, Dhaka, Bangladesh. p.143.

Baburatan. P., S. Eswarareddy and Y. Narayanareddy. 1993. Influence of water soaking of Annona (Annona squamosa L.) seed on germination and subsequent seedling growth. South Indian Hort. 41: 171-173.

Bhuiyah, M. I. M. 2001 . Damage of sonic stored pulses by the pulse beetle, Callosobruchus chinensis (Linn.) and its control with botanicals. Ph.D. Thesis. Department of Entomology, Bangladesh Agricultural Univ., Mymensingh, Bangladesh. pp. 1-149.

Freed. R. D. 1992. MSTAT-C. Crop and Soil Science Department, Michigan State University, USA. 
Grainge, M. and S. Ahmed. 1988. Handbook of Plants with Pest Control Properties. John Wiley and Sons. New York; 470.

ISTA (International Seed Testing Association) 1976. International Rules for Seed Testing. Seed Sci. Tech. 4: 3-9.

Karim. A. N. M. R. 1994. Status of botanical pest control in Bangladesh. Paper Presented at the Expert Consultation on Regional Perspective for Use of Botanical Pesticides in Asia and the Pacific, Bangkok, Thailand.

Khatun, A., M. A. H. Bhuiyan and A. Ayub. 2008. Storability of lentil (Lens culinaris L.) seed as influenced by seed collection. Bull. Inst. Trop. Agr. Kyushu Uviv. 31: 1-8.

Khatun. A., G. Kahir and M. A. H. Bhuiyan. 2009. Eftèct of harvesting stages on the seed quality of lentil (Lens culinaris L.) during storage. Bangladesh J. Agril. Res. 34(4): 565-576.

Ponnuswamy, R. L., R. H. Miller and W. H. Luckmann. 1991. Introduction to Insect Pest Management. John Wiley and Sons, New York. 235-273 pp.

Reddy, Y. T. N. and M. M. Khan. 2001. Effect of osmopriming on germination, seedling growth and vigour of khirni (Mimusops hexandra) seeds. Seed Res. 29(1); 24-2 7.

Savitri, H., M. S. Reddy and B. M. Reddy. 1994. Effect of seed treatment with fungicides and insecticides on seed-borne fungi, storage insect pest, seed viability and seedling vigour of sorghum. Seed Res. 22(2): 146-1 55.

Shahjahan. M. 2003. Storage effect on the nutritional quality of three major pulses, $\mathrm{Ph}$. D, thesis, Department of Biochemistry and Molecular Biology, University of Dhaka, pp. $1-191$. 